\title{
EARTH SCIENCE APPLICATIONS IN THE FIELD OF ARCHAEOLOGY: THE HELIKE EXAMPLE
}

\author{
Katsonopoulou Dora \\ The Helike Project, Director, eliki@otenet.gr
}

\begin{abstract}
Earth science applications are widely used in the field of archaeology today. The Helike Project made use of such applications at a time when archaeology in Greece was mostly limited to traditional methodology only. Thus Helike constitutes a pioneer study case of such investigations and of their usefulness in the field of archaeology. In searching for Ancient Helike, our team since 1988 combined extensively traditional archaeological research methods and geophysical and geological exploration. The results of this multidisciplinary approach were in most cases successful beyond expectations. In this paper, I present and discuss the most significant archaeological discoveries in the area of Helike based primarily on data from our geological and geophysical investigations the last 20 years.
\end{abstract}

Key words: Helike, poros, Early Helladic Rizomylos, Dye-Works Valimitika, Mycenaean Geometric Nikolaiika, Roman road.

\section{Introduction}

The exact location of Helike on the southwestern shore of the Corinthian Gulf remained for decades an unsolved riddle for archaeology. The Helike Project began a search for the city in 1988 using surface surveys, geophysical exploration and extensive bore hole drilling to solve an archaeological question at a time when archaeology in Greece was mostly limited to traditional methodology only. The significant results of the multidisciplinary research in Helike show in a prominent way the usefulness and effectiveness of such investigations in the field of archaeology.

According to ancient sources, Helike was founded in Mycenaean times and was destroyed by a catastrophic earthquake in $373 \mathrm{BC}$, after over a thousand years of prosperity. The earthquake happened on a winter night and was preceded with a variety of unusual phenomena including the appearance of comets and animals deserting Helike five days prior to the earthquake (Katsonopoulou 2005a). The destruction was the result of two combined natural forces: earthquake and tsunami. The earthquake caused the sea to rise to an immense height and completely flood the city, along with the sanctuary of Helikonian Poseidon worshipped in Helike as the god of waters and earthquakes (Katsonopoulou 2009).

\section{The research}

The erroneous interpretation of the reported submergence of Helike under seawaters led scholars in the past to seek the lost city beneath the Corinthian Gulf, with inconclusive results (Katsonopoulou 1991). 


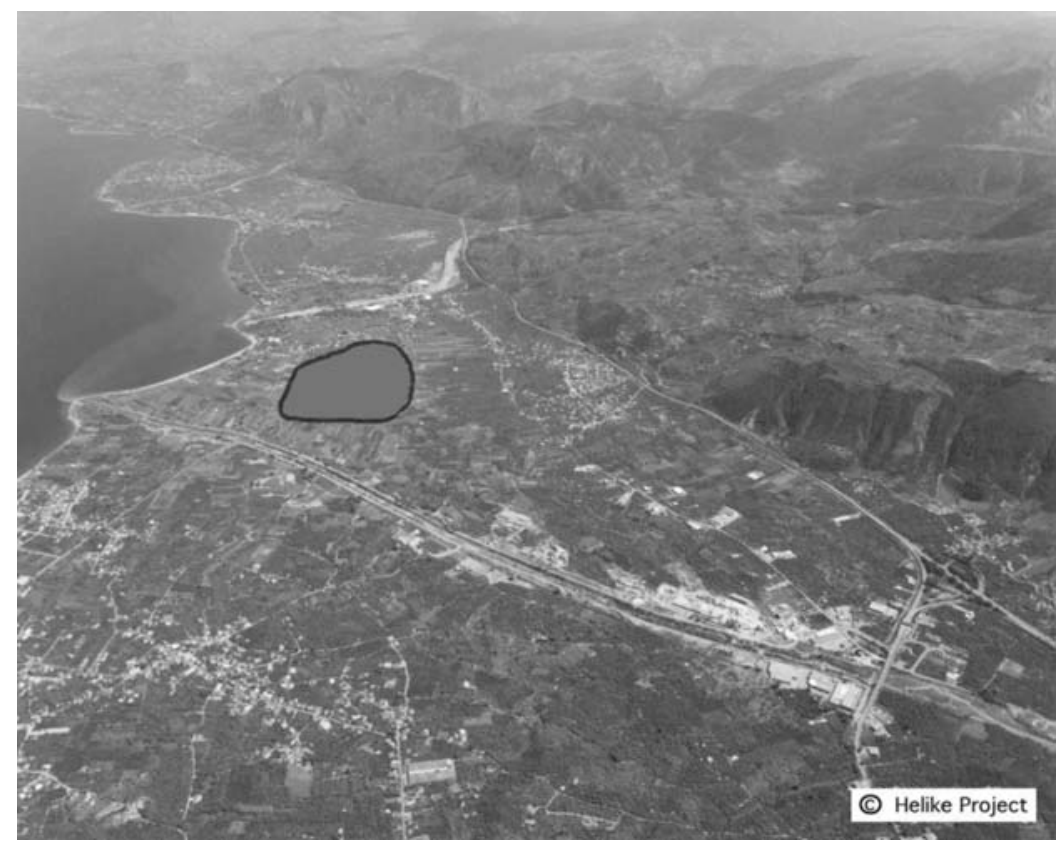

Fig. 1: Aerial view of the Helike Delta, looking southeast, between the Gulf of Corinth (left) and the mountains of the Peloponnesos (right). Three rivers cross the delta: the Selinous (foreground), Kerynites (midground) and Vouraikos (background). The black circle indicates the approximate location of the ancient lagoon.

Surprisingly, the scholars overlooked a critical source on Helike's location. The $3^{\text {rd }}$ century BC philosopher and mathematician Eratosthenes visited the area of Helike about 150 years after the catastrophe. He was told by the ferrymen that the bronze statue of Poseidon, holding a hippocamp (a sea horse) in one hand, stood in the poros and was dangerous for those fishing with nets. The word poros used by Eratosthenes must be interpreted as indicating the existence of a narrow passage of water in the place where the city of Helike stood before the earthquake (Katsonopoulou 1995 and 2005a). This would imply that a lagoon was formed as a result of the $373 \mathrm{BC}$ earthquake and the subsequent tsunami. A similar lagoon probably existed in the vicinity of Helike before the earthquake, and was presumably enlarged by the earthquake.

Consistent with this interpretation, in 1991 The Helike Project launched a search for Helike on dry land, and soon found substantial evidence of the existence of an ancient lagoon under today's coastal plain, covering an area of about $1.5 \mathrm{~km}^{2}$ in a NW-SE direction between the Selinous and Kerynites rivers (Fig. 1). In the center of this area, at a depth of about $3 \mathrm{~m}$, buried under lagoonal strata, were discovered remains of Classical walls showing evidence of destruction by earthquake and accompanying tsunami. The location of these ruins (Fig. 2, B) is in complete agreement with the reported location of Helike forty stadia (about $7 \mathrm{~km}$ ) east of Aigion, according to Pausanias (7.24.5).

Systematic excavations carried out in the region by The Helike Project since 2000 justified in an impressive way the results of borehole drilling and geophysical exploration in the area in previous years. A magnetometry survey carried out in 1994 at the Klonis field in contemporary Eliki (Fig. 2, $\mathrm{Kl}$ ), near the center of the area in which our borehole drilling showed evidence of ancient occupation, revealed promising targets buried about $2 \mathrm{~m}$ below the surface (Papamarinopoulos et al. 1998). 


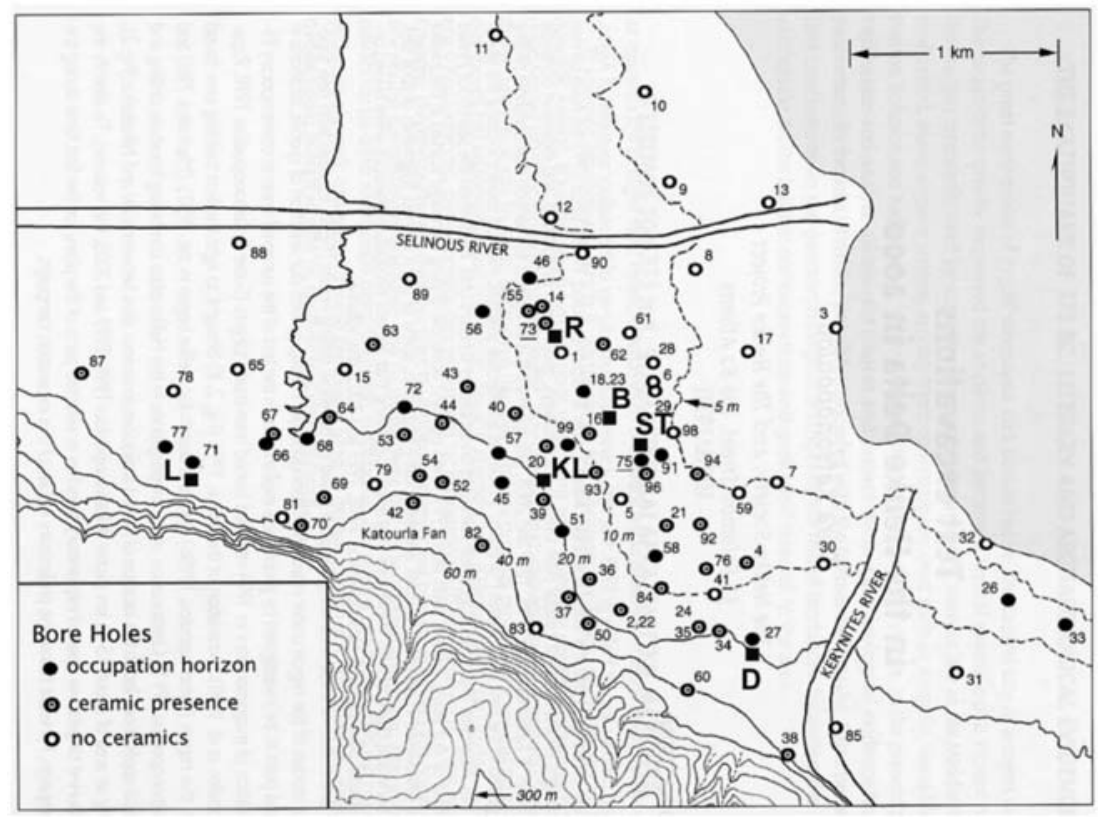

Fig. 2: Topographic map of the central Helike area, showing locations of boreholes (numbered circles) and locations of archaeological sites (written in capital letters) from the Greek Army 1:5000 map (adapted from Katsonopoulou 2005, Fig. 1, p. 34).
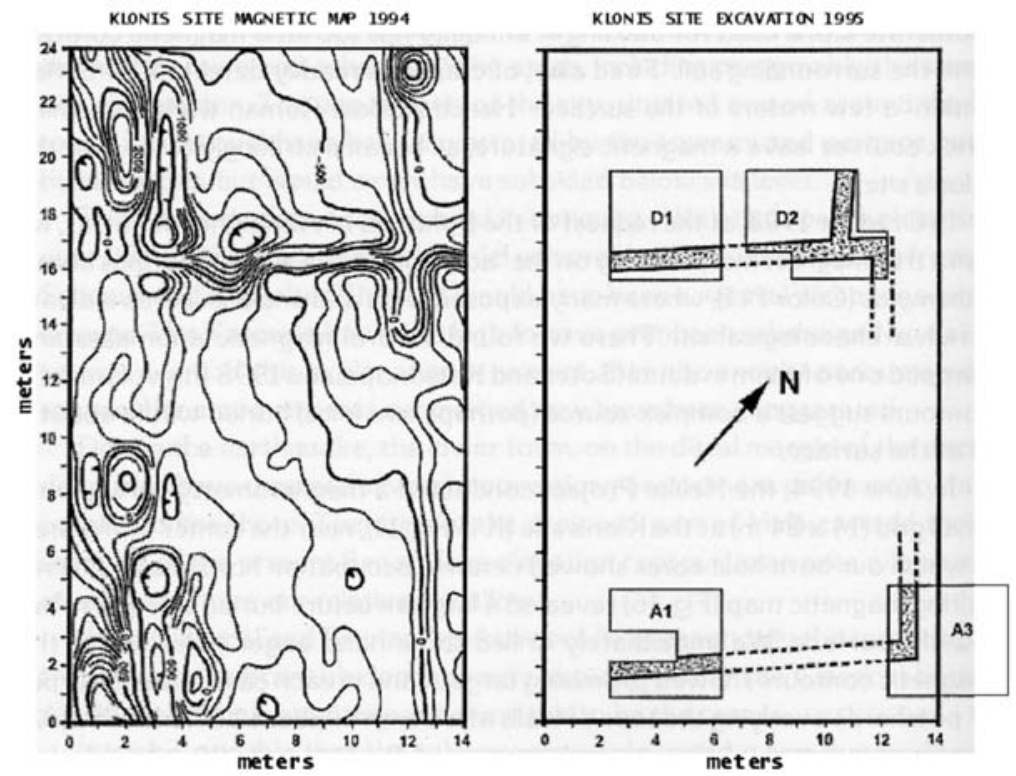

Fig. 3: Contours of magnetic intensity conducted at the Klonis site in 1994 (left). Plan of the excavated squares in 1995 (right), showing locations of walls corresponding to the magnetic contours (from Soter \& Katsonopoulou 1998, Fig. 16, p. 106). 
Excavations conducted at this location in 1995 following the geophysical survey, brought to light part of a large rectangular Roman building with walls standing about $2 \mathrm{~m}$ high. The typical Roman construction of the walls, with alternating courses of unworked stone and baked brick, apparently account for the excellent correlation between the magnetic data and the recovered walls (Fig. 3). An extensive destruction layer of fallen stones, bricks, plaster and roof tiles, found both within and outside the building, shows that it was destroyed by an earthquake, most probably in the $5^{\text {th }} \mathrm{c}$. AD (Katsonopoulou 1998).

It is worthy to note that major discoveries in Helike's area, successfully located on dry land by our team, are primarily the results of the multidisciplinary methodology we applied in our search. I will describe below the most prominent of these discoveries.

\section{The Early Helladic settlement in Rizomylos}

Borehole B75 was drilled to a depth of $11 \mathrm{~m}$ in the field of Panagiotis Saitis in Rizomylos in 1998 (Fig. 2, ST). It is perhaps the most impressive of the boreholes drilled in the Helike plain between 1991 and 2002. Many core samples from alternating layers of greenish/gray silt and clay contained a variety of anthropogenic indicators: potsherds, burned bone and charcoal in a continuous depth from about 3 to $6.6 \mathrm{~m}$, strongly suggesting the existence of a buried ancient site in this area. Thus, the location was selected among the first to be tested by means of excavation in 2000 , when our first excavations campaign began in the Helike plain.

Trench H7, was opened near the location of borehole B75 and its results were indeed rewarding. At a depth of 3.3-3.6 m, we brought to light remains of Early Bronze Age walls, 0.6-1 m wide, built with different types of unworked stone in an impressive variety of color: gray limestone, red, green and orange color psamite stones, and conglomerate gray psamites. In few instances red chert and black dolomite stone were also used (Katsonopoulou 2005b). Continuation of excavations in the following years revealed that in Rizomylos are preserved the extensive remains of an EH II-III settlement (25002200 BC) buried between 3-5 m under the coastal plain sealed under lagoonal sediments. The EH architectural remains brought to light so far in the Helike plain belong to large rectilinear buildings made of stone foundations and upper walls built with sun-dried bricks and coated with clay. The floors inside the buildings consist of packed earth but also quite often are made of pebbles. The buildings are constructed according to organized town planning flanking the sides of cobbled streets and open areas (Fig. 4). They are furnished with architectural features showing advanced technological level such as inside benches, stone platforms and clay architectural plinths (Katsonopoulou 2007 \& 2010).

The pottery found in the rooms of the excavated buildings is amazingly rich in number, shapes, and decoration, including an impressively large number of complete pots (Katsarou-Tzeveleki 2010). Other finds from the excavated rooms and exterior areas include pointed bone tools, spherical stone tools, terracotta objects, such as spindle whorls and spools, obsidian blades and flint objects for cutting and scraping activities. Food remains include sea shells and animal bones. Remains of seeds were found inside some of the recovered vases.

Excavation data from the Early Helladic settlement suggest that it was destroyed by an earthquake and accompanying fire, and that it was immediately abandoned, thereby leaving its contents intact, sealed under thick clay deposits. Analysis of sediments covering these early ruins showed remnants of a mixture of freshwater, brackish, and marine microfauna, indicating that the site was buried under the sediments of a lagoon, which actually protected it from any later human intervention (Alvarez-Zarikian et al. $2005 \&$ 2008). 


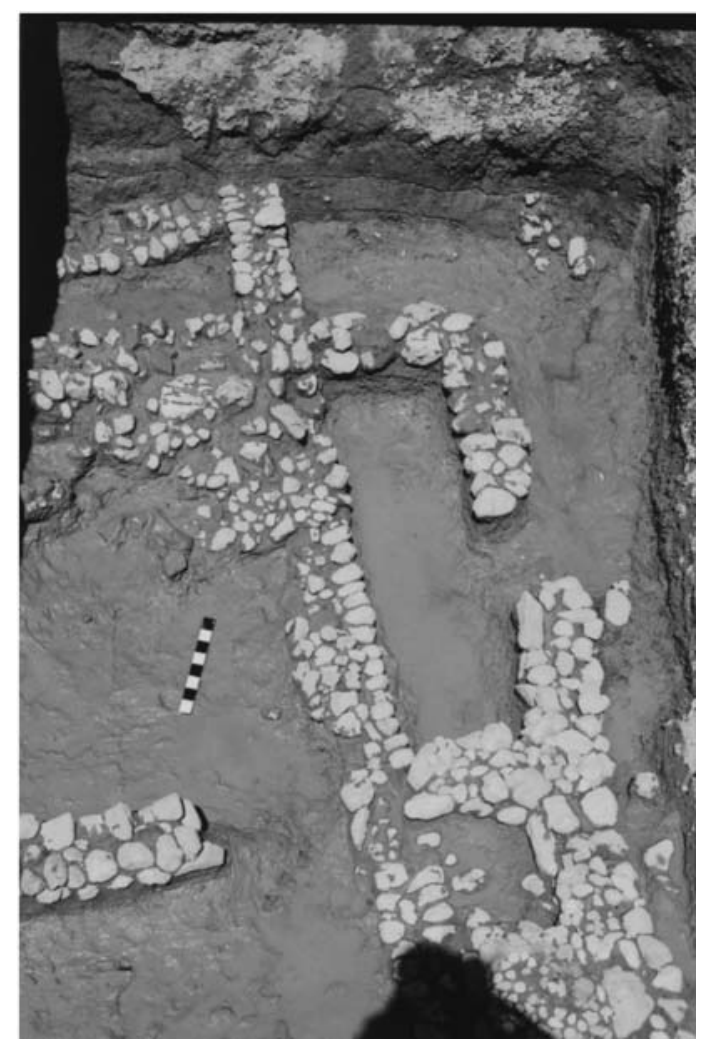

Fig. 4: Architectural remains of an Early Helladic building, probably a "corridor house", revealed in trench H38 in Rizomylos in 2003.

\section{The Mycenaean-Geometric site in Nikolaiika}

An unexpected discovery was made by our team during the 2006 excavation season in the area of Nikolaiika about $1.2 \mathrm{~km}$ east of the Early Helladic settlement in Rizomylos. The location was first explored in 1993 when we drilled borehole B27 to a depth of $20 \mathrm{~m}$ (Fig. 2). We discovered fragments and chips of ceramics in several core samples recovered from near the surface to about $4 \mathrm{~m}$ depth suggesting the presence of occupation horizons at this location (Soter and Katsonopoulou 1999). Excavation of trench $\mathrm{H} 58$ in 2006 brought to light a group of well constructed tile-covered Roman tombs $\left(3^{\text {rd }}-4^{\text {th }} \mathrm{c} . \mathrm{AD}\right)$ at about $1.3 \mathrm{~m}$ below the surface and in the underlying strata, from $2-4 \mathrm{~m}$, fine quality pottery layers dated to the Geometric and Mycenaean times (Fig. 2, D). These are two important chronological phases for Helike's history. The city, according to the sources, was founded in Mycenaean times by Ion $\left(14^{\text {th }} / 13^{\text {th }} \mathrm{c}\right.$. BC) (Katsonopoulou 1999) and sent her most important colony to the West, the famous Sybaris, in the Geometric period $\left(8^{\text {th }} \mathrm{c}\right.$. BC). Continuing excavations following the 2006 season, revealed new Geometric pottery layers including a circular hearth and a well built long wall of Late Classical-Early Hellenistic times, most probably an enclosure wall.

\section{The Hellenistic Dye-Works in Valimitika}

In the western area of the Helike region near the Selinous river, combined application of georadar (Fig. 5) and borehole drilling detected targets of interest at depths between 2 and $3 \mathrm{~m}$ (Kutrubes et al. 2003). 


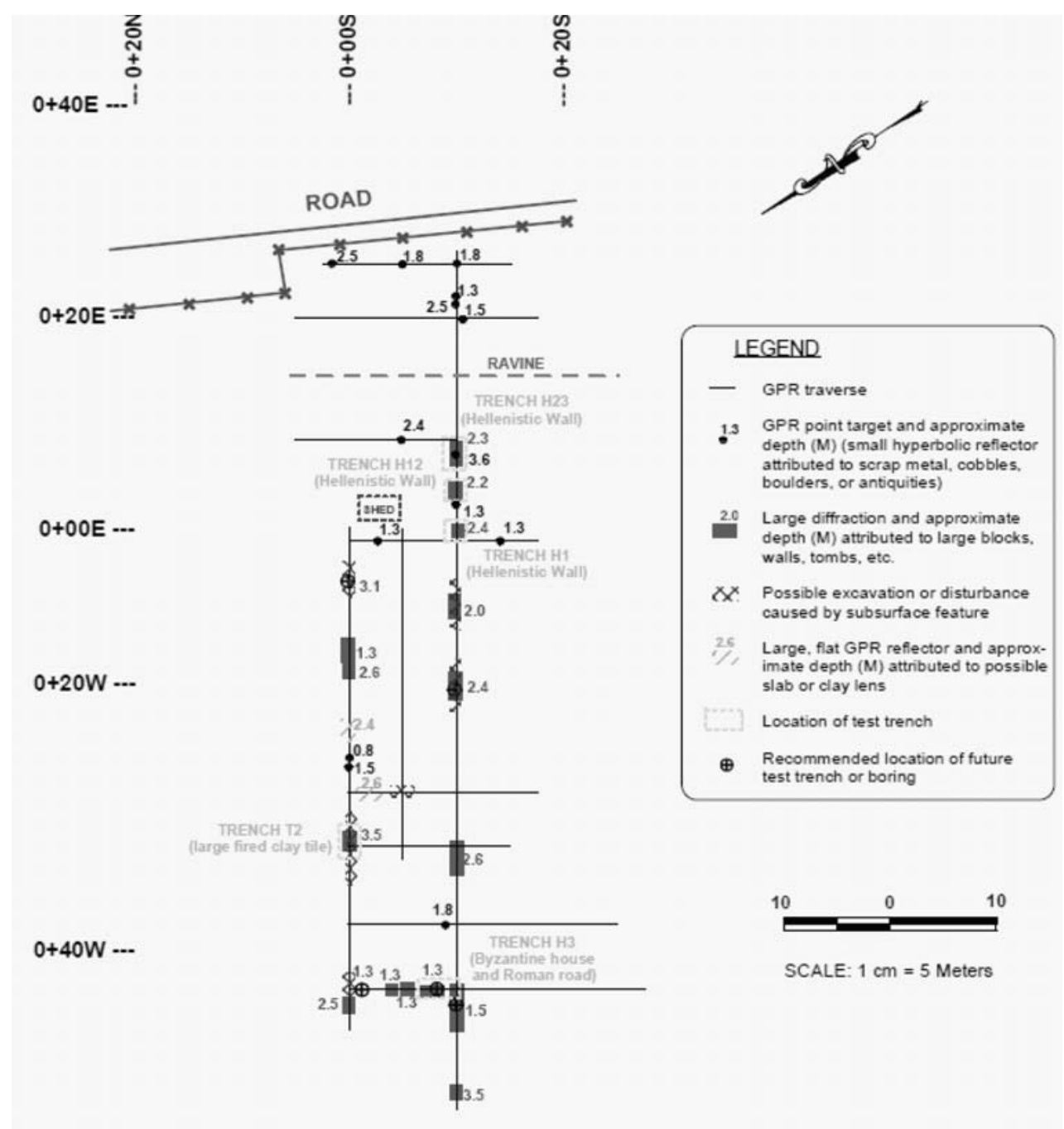

$0+60 \mathrm{~W}-\cdot$

Fig. 5: Results of the 1996 GPR survey at the Romanos site in Eliki/Valimitika and locations of excavated trenches H1, H12 and H23, where Hellenistic walls were revealed (from Kutrubes et al. 2003).

Excavation of a number of trenches from 2000 onwards at this location (Fig. 2, R) revealed important archaeological finds. At a depth of about $2.3 \mathrm{~m}$ from the surface, came to light architectural remains of Hellenistic structures including a rare building of Dye-Works, preserving a complex of four pebbled floor basins and other installations for washing and dyeing fabrics in an excellent state of preservation (Fig. 6). Associated finds from the excavated areas of the building are abundant. The large array of pottery includes black glazed, red glazed, West Slope and relief decorated vases. Other finds include clay lamps, clay loom weights, metal objects in bronze, iron and lead, and a rich collection of bronze coins, mainly Sicyonian and of the Achaean League. Among the finds, we note the discovery of a terracotta statuette of a Tanagra lady. 


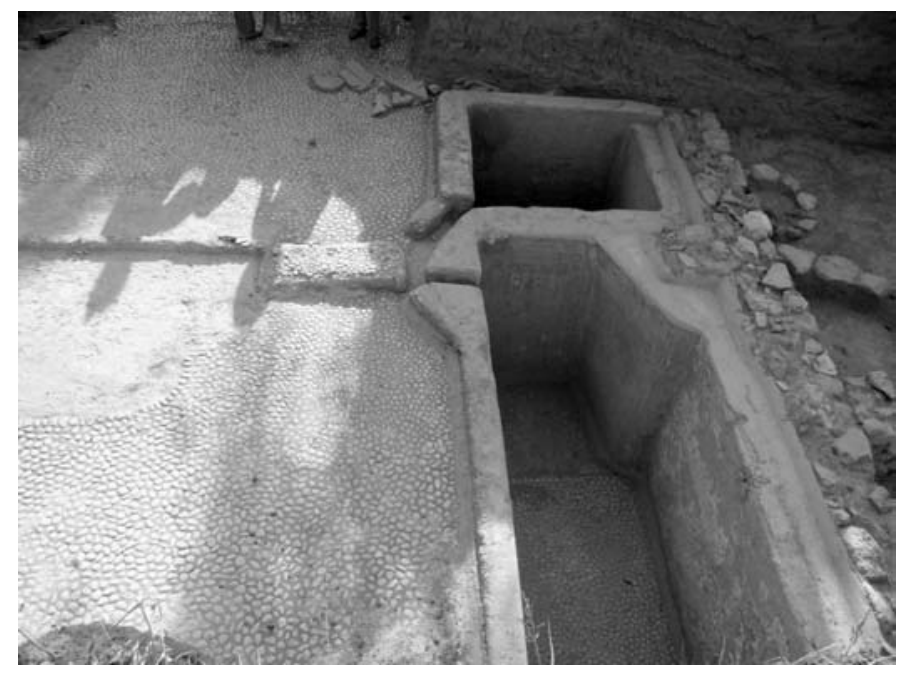

Fig. 6: The well preserved Hellenistic four pebbled floor basins complex in Valimitika and plastered channels.

\section{The Roman road through the Helike Plain}

In the same area, in a horizon overlying the Hellenistic structures was discovered another unique find. Segments of a Roman cobbled road (Fig. 7), 5-6 m wide, extending in a straight line through the Helike plain. The road was excavated in a total of 9 trenches between the Hellenistic (Fig. 2, R) and the Early Bronze Age Helike sites (Fig. 2, ST). Consequently, its course was detected by resistivity tomography between the Selinous and Kerynites rivers $1.3 \mathrm{~km}$ long (Tsokas et al. 2009). The location of the Roman road at this position about 200-300 m southwest of the modern railroad line (Fig. 8), where the northern edge of the ancient lagoon lies, suggests that by Pausanias' time the lagoon was mostly silted over, making the construction of a major coastal road possible.

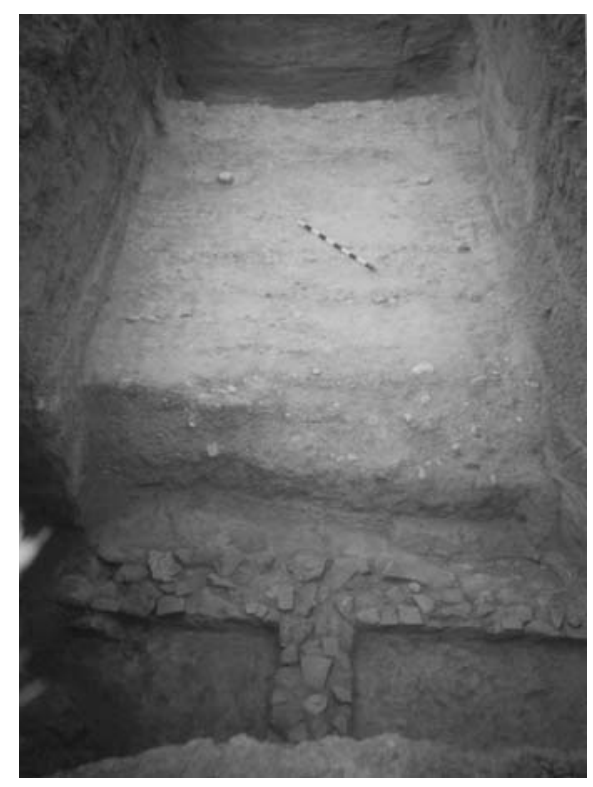

Fig. 7: Trench $\mathrm{H} 12$ showing part of the $5 \mathrm{~m}$ wide Roman road. In an older horizon in the southern section of the trench are revealed Hellenistic walls. 


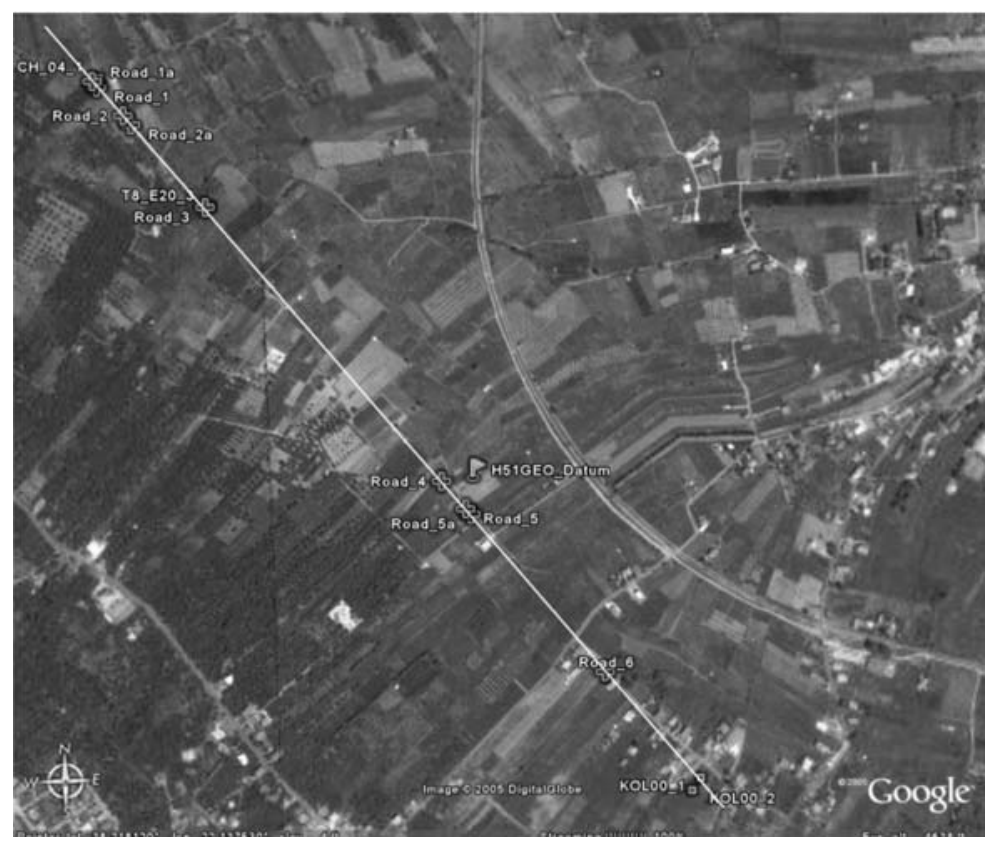

Fig. 8: The $2 \mathrm{~km}$ investigated course of the Roman road through the Helike plain. Excavation and resistivity tomography located the road at a length of $1.3 \mathrm{~km}$ between the locations Road 1 (west) and Road 6 (east).

During a description of his journey through the region, Pausanias $\left(2^{\text {nd }} \mathrm{c} . \mathrm{AD}\right)$ narrates that after visiting the town of Aigion, he proceeded east and at a distance of about $7 \mathrm{~km}$ arrived at a place by the sea named Helike. This place was at the same location where the city of Helike and the holiest sanctuary of Helikonian Poseidon existed before (Paus. 7.24.5). The traveller further noted that ruins of Helike, although corroded by seawater, could be seen beneath the water (Paus. 7.24.13). Indeed, in the area of Rizomylos, we discovered the Roman road and, in deeper horizons underneath, at three different locations, remains of Classical, Hellenistic and Early Bronze Age walls.

\section{The new Hellenistic site in Eliki}

Another impressive example of unexpected archaeological discoveries based on geoarchaeological data from borehole B71 drilled in 1998 (Fig. 2), is the most recent discovery of notable ancient walls in another location about $1 \mathrm{~km}$ west of the contemporary village of Eliki, near the foothills. Excavation of trench H64 (Fig. 2, L) in 2009, brought to light architectural remains of ancient buildings with well built walls, $0.55-0.65 \mathrm{~m}$ wide, preserved up to $0.5 \mathrm{~m}$ high, dated on the basis of associated pottery and other finds to the Hellenistic times. The discovery of Hellenistic structures at this location, more than $1.5 \mathrm{~km}$ southwest of the Hellenistic site and the Dye-Works establishment discovered in the northern area of contemporary Eliki/Valimitika in previous years, suggests extensive habitation of the western part of the Helike region in the period following shortly after the destructive event of 373 BC. The 2009 excavation data shed new light on the ancient habitation pattern in the area, reportedly completely abandoned and deserted as a result of the seismic phenomenon, thus leading to reconsideration of the reported disastrous earthquake effects in the region of Helike, in the period following the destruction of $373 \mathrm{BC}$. 


\section{References}

Alvarez-Zarikian, C.A., S. Soter, D. Katsonopoulou, P. Blackwelder and T. Hood 2005. Microfaunal evidence for paleoenvironment of the Helike Delta. In D. Katsonopoulou, S. Soter \& I. Koukouvelas (eds.), Ancient Helike and Aigialeia. Archaeological Sites in Geologically Active Regions, Helike III. The Helike Society. Athens, 183-195.

Alvarez-Zarikian, C.A., S. Soter and D. Katsonopoulou 2008. Recurrent submergence and uplift in the area of Ancient Helike, Gulf of Corinth, Greece: microfaunal and archaeological evidence. Journal of Coastal Research, 24, 1A, 110-125.

Katsonopoulou, D. 1991. Ancient Helike. History and modern research (in Greek). In A. Rizakis (ed), Achaia und Elis in der Antike, Meletemata 13. The National Foundation Research Center. Athens, 227-234.

Katsonopoulou, D. 1995. Helike (in Greek). Archaiologia, 54, 40-45.

Katsonopoulou, D. 1998. The first excavation at Helike: Klonis Field. A preliminary report (in Greek with extended abstract in English). In D. Katsonopoulou, S. Soter \& D. Schilardi (eds.), Ancient Helike and Aigialeia, Helike II. The Helike Society. Athens, 125-145.

Katsonopoulou, D. 1999. Mycenaean Helike. In P.P. Betancourt, V. Karageorghis, R. Laffineur and WD. Niemeier (eds.), Meletemata, Studies in Aegean Archaeology Presented to Malcolm H. Wiener as he Enters his $65^{\text {th }}$ Year, Aegaeum 20. Universite de Liege \& UT-PASP. Liege-Austin, 409-414.

Katsonopoulou, D. 2005a. The earthquake of 373 BC. Literary and archaeological evidence. In D. Katsonopoulou, S. Soter \& I. Koukouvelas (eds.), Ancient Helike and Aigialeia. Archaeological Sites in Geologically Active Regions, Helike III. The Helike Society. Athens, 15-32.

Katsonopoulou, D. 2005b. Test excavations in the Helike Delta in 2000. In D. Katsonopoulou, S. Soter \& I. Koukouvelas (eds.), Ancient Helike and Aigialeia. Archaeological Sites in Geologically Active Regions, Helike III. The Helike Society. Athens, 33-65.

Katsonopoulou, D. 2007. Early Helladic settlement at Helike (in Greek). In E. Konsolaki-Giannopoulou (ed.), EП $\Theta \Lambda O N$, Proceedings of International Conference on the Archaeology of Poros). Municipality of Poros. Athens, 117-126.

Katsonopoulou, D. 2009. The Pan-Ionic cult and sanctuary of Helikonios Poseidon in Helike of Achaea, Greece. In: Proceedings of International Conference on Indo-European Linguistics and Classical Philology, June 22-24 2009, St. Petersburg, Russia, 261-272.

Katsonopoulou, D. 2010. The Early Helladic settlement at Helike: an Early Bronze Age center in Achaea. In D. Katsonopoulou (ed.), The Early Helladic Peloponnesos, Helike IV. The Helike Society, in print.

Katsarou-Tzeveleki, St. 2010. Morphology and distribution of pottery in the Early Helladic settlement at Helike, Achaea. In D. Katsonopoulou (ed.), The Early Helladic Peloponnesos, Helike IV. The Helike Society, in print.

Kutrubes, D.L., S. Soter, D. Katsonopoulou \& A. Heinze 2003. Ground penetrating radar in the search for Ancient Helike, Greece. In SAGEEP Proceedings, 92-106.

Papamarinopoulos, St. P., P. Stefanopoulos \& M. Papaioannou 1998. In D. Katsonopoulou, S. Soter \& D. Schilardi (eds.), Ancient Helike and Aigialeia, Helike II. The Helike Society. Athens, 147-151.

Soter, S. \& D. Katsonopoulou 1999. Occupation horizons found in the search for the ancient Greek city of Helike. Geoarchaeology, 14, 6, 531-563.

Tsokas, G.N., P.I. Tsourlos, A. Stampolidis, D. Katsonopoulou \& S. Soter 2009. Tracing a major Roman road in the area of Ancient Helike by resistivity tomography. Archaeological Prospection, 16, 251-266. 